\title{
RUSSIAN REAL SECTOR OF THE ECONOMY IN MAY 2015: FACTORS AND TRENDS
}

\author{
O.Izryadnova
}

The decline in economic growth rates in 2015 is determined by contraction in both investment and consumer demand. Fixed investment in May 2015 decreased by $7.6 \%$ and retail turnover by 9.2\% compared to May 2014. The narrowing of domestic demand increased the downtrend in industrial production. On a year-over-year basis, the manufacturing output index in May 2015 stood at 91.7\% and the mineral extraction index was 99.1\%.

The economic situation in 2015 is determined by simultaneous contraction of investment and consumption demand. The volume of fixed investment in May 2015 compared to May 2014 decreased by $7.6 \%$ and retail turnover by $9.2 \%$. The narrowing of domestic demand increased the downtrend in industrial production whose index dropped by 5.5\% compared to May 2014.

Net exports whose contribution increased due to a deeper decline in imports versus supplies of Russian goods to external markets remained a factor containing the effect of falling domestic demand on GDP dynamics in Q1 2015.

An analysis of the dynamics and composition of the produced GDP shows that the tradable sector, accounting for almost $60 \%$ of fixed investments and $50 \%$ of all jobs in Q1 2015, remained a factor which contained adverse developments. The period of Q1 2015 was characterized by changes in the growth pattern of the tradable sector by branch of economic activity: production cuts in the manufacturing sector were offset by growth in the agricultural industry and the mineral

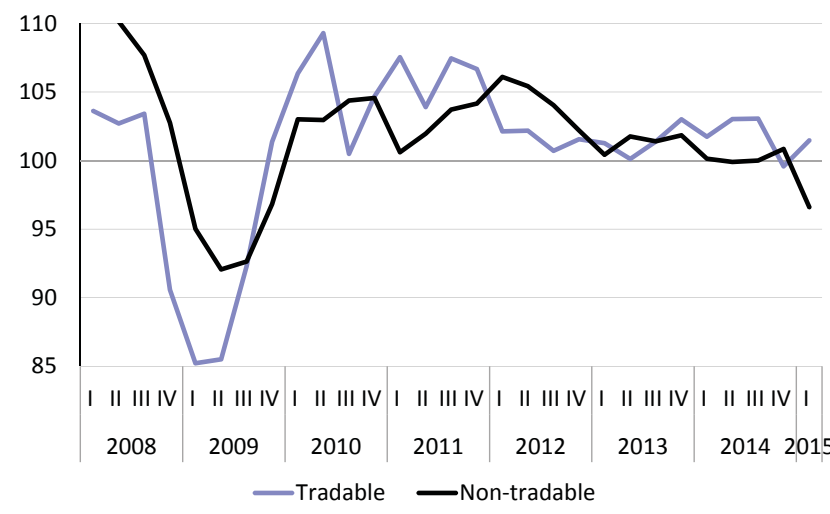

Source: Rosstat (Russia's Federal State Statistics Service). Fig. 1. GDP dynamics for tradable and non-tradable sectors of the economy in 2008-2015, percentage change from corresponding quarter of previous year

extraction sector. Conversely, in Q1 2013-2014, the dynamics of the tradable sector was governed predominantly by outpacing growth in the manufacturing sector (Fig. 2).

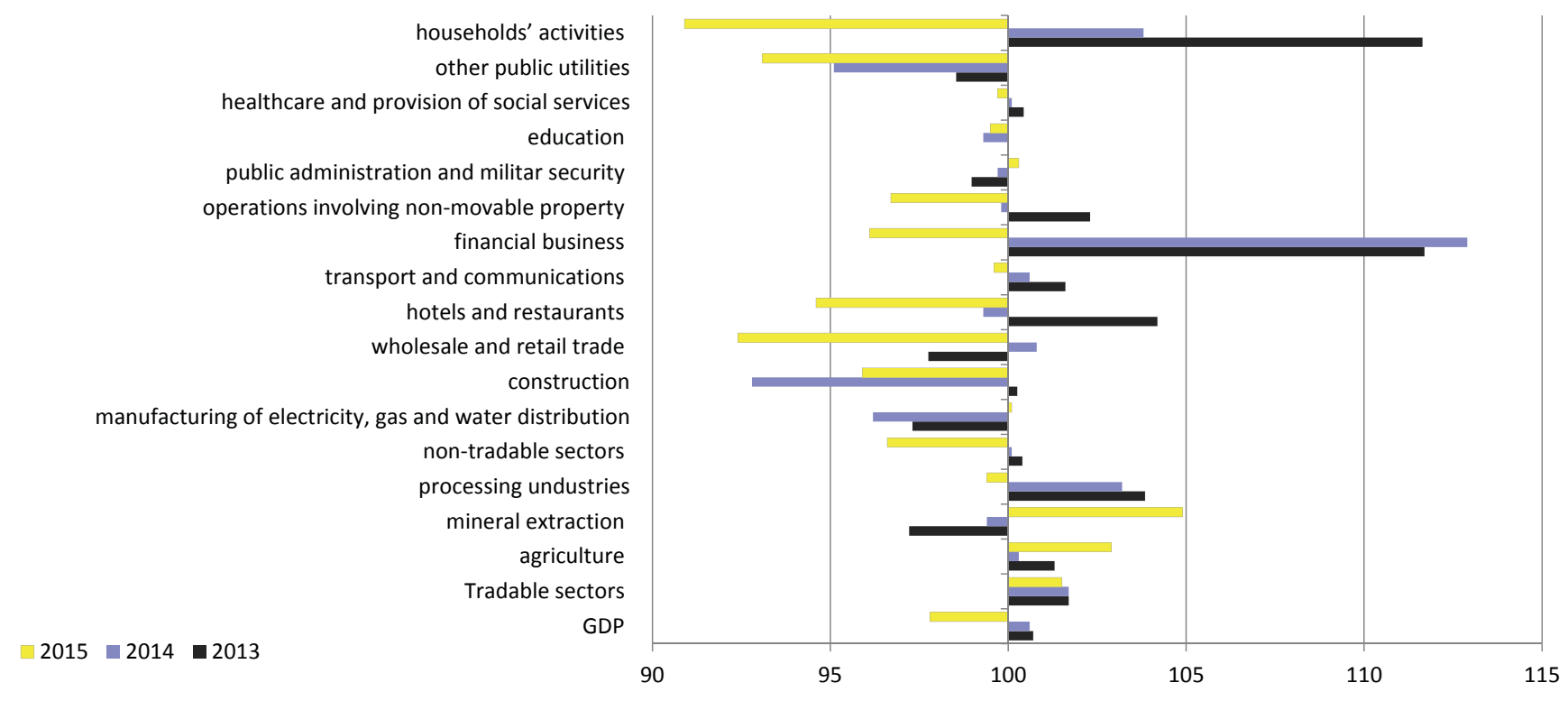

Source: Rosstat.

Fig. 2. Indices of the physical volume of produced GDP and gross value added by branch of economic activity in Q1 2013-2015, percentage change from corresponding period of previous year 
The dynamics of the non-tradable sector of the economy has since 2014 been hit worst by the slowdown in domestic demand. In Q1 2015, this sector saw a decline of 3.4\% from Q1 2014 in the production of Gross Value Added (GVA) for the first time since 2009. There is decline in production in the non-tradable sector of the economy in all of the monitored aggregate activity types, except public administration and military security $(100.3 \%$ compared to Q1 2014) and production and distribution of electric power and water (100.1\%) (Fig. 2).

The situation in Q1 2015 governed the key trends in the coming two months. The decline in domestic demand increased in the period between April and May 2015. On a year-over-year basis, in May 2015 fixed investment stood at $92.4 \%$, retail turnover at $90.8 \%$ and industrial output at $94.5 \%$. The manufacturing and mineral extraction sectors in May 2015 dropped respectively by $8.3 \%$ and $0.8 \%$ compared to May 2014 .

The output of the manufacturing sector in May 2015 saw a y-o-y decline in almost all of the monitored branches of economic activity, except the manufacture of chemicals and chemical products. The growth of $8.0 \%$ from May 2014 in the manufacture of chemicals and chemical products was determined particularly by a $17.7 \%$ growth in the manufacture of pharmaceuticals and a $9.1 \%$ increase in the output of basic chemical products with high percentage of export goods. The Russian pharmaceutical industry increased the output of Russia-made pharmaceuticals amid steadily decelerating growth in prices of medicaments in response to the changes in market trends, the decline in the exchange rate of the national currency and import cuts. Additionally, there are investment projects in progress as part

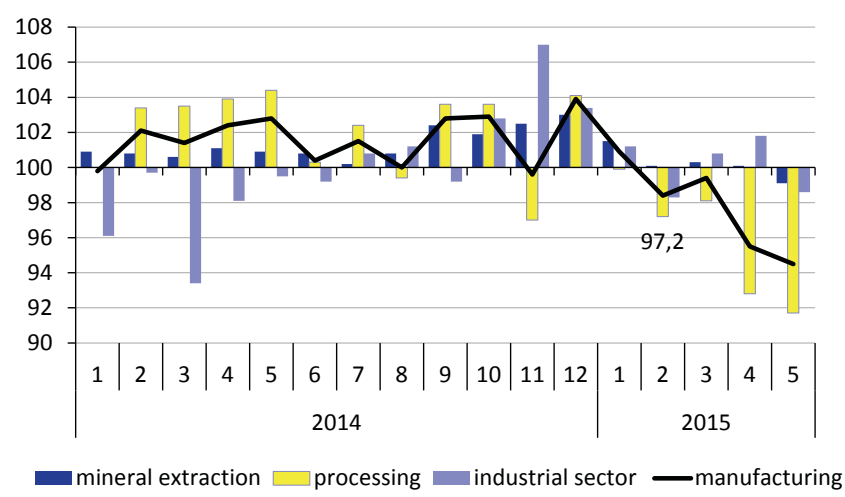

Source: Rosstat.

Fig. 3. The dynamics of industrial output by branch of economic activity in 2014-2015, percentage change from corresponding month of previous year

of the Farma 2020 Program, which are focused on import substitution ${ }^{1}$.

The situation with production of consumption goods is governed by a decline in consumer demand. On a year-over-year basis, the wholesale turnover of food products in May 2015 stood at $91.2 \%$ and nonfood products at $90.4 \%$. The low consumer demand, which doesn't encourage production, was determined by a $6.4 \%$ decline in real personal incomes and a $7.3 \%$ decrease in wages compared to May 2014. Consumer demand remains extremely low and doesn't encourage production despite that inflation slowed down and the dynamics of prices of consumer-goods improved. In May 2015, the manufacture of food products dropped by $1.5 \%$, the manufacture of textiles and clothing by $23.8 \%$, the manufacture of leather and footwear by

1 See Section 3, OMES No. 10, 2015.

Table 1

INDICES OF PRODUCTION BY KEY TYPE OF MANUFACTURING IN 2015, PERCENTAGE CHANGE FROM CORRESPONDING MONTH OF PREVIOUS YEAR

\begin{tabular}{|l|c|c|c|c|c|}
\hline & January & February & March & April & May \\
\hline Manufacturing & 99.9 & 97.2 & 98.1 & 92.8 & 91.7 \\
\hline manufacture of food products & 103.6 & 104.6 & 102.3 & 99.4 & 98.5 \\
\hline manufacture of textiles and clothing & 72.5 & 117.2 & 105.3 & 100.7 & 76.2 \\
\hline manufacture of leather, leather goods and manufacture of footwear & 88.2 & 80.8 & 84.3 & 82.7 & 84.7 \\
\hline woodworking and manufacture of goods & 81.9 & 111.5 & 107.5 & 96.4 & 93.1 \\
\hline manufacture of pulp, paper and paperboard & 93.8 & 77.3 & 78.7 & 82.5 & 88.1 \\
\hline manufacture of coke and petrochemicals & 102.6 & 103.3 & 100.9 & 101.8 & 99.3 \\
\hline manufacture of chemicals and chemical products & 88.4 & 106.1 & 111.0 & 93.4 & 108.0 \\
\hline manufacture of rubber and plastics products & 71.4 & 116.4 & 108.6 & 101.5 & 90.8 \\
\hline manufacture of non-metallic mineral products & 77.0 & 110.7 & 117.8 & 100.6 & 88.5 \\
\hline metallurgy and manufacture of finished metal products & 80.8 & 100.4 & 109.4 & 98.7 & 88.8 \\
\hline manufacture of machinery and equipment & 90.7 & 87.2 & 95.7 & 85.1 & 75.1 \\
\hline manufacture of electrical, electronic and optical equipment & 95.2 & 93.1 & 93.9 & 99.3 & 87.6 \\
\hline manufacture of means of transport and equipment & 87.2 & 77.6 & 94.8 & 77.8 & 82.2 \\
\hline other manufacture branches & 89.2 & 87.1 & 100.0 & 93.8 & 76.2 \\
\hline
\end{tabular}

Source: Rosstat. 
$15.3 \%$, on a year-over-year basis. The retail market development was conditioned by a decline in both domestic production and imports. Consumption goods accounted for $36.4 \%$ of total imports within the structure of imports in Q1 2015, down 1.9 p.p. compared to the corresponding period last year. The decline in imports with spiking prices of imported goods widened niches for domestic goods in the domestic market ${ }^{1}$. Domestic goods in Q1 2015 accounted for $61.0 \%$ of the structure of retail turnover commodity resources, with food products $68.0 \%$, an increase of 4 p.p. compared to the corresponding period last year.

STRUCTURE OF RETAIL TRADE COMMODITY RESOURCES IN ACTUAL PRICES, \%

\begin{tabular}{|l|c|c|c|} 
& $\begin{array}{c}\text { Retail trade com- } \\
\text { modity resources }\end{array}$ & \multicolumn{2}{|c|}{ Including } \\
\cline { 3 - 4 } & \multicolumn{2}{|c|}{2014} & \\
domestic & imported \\
\hline $1^{\text {st }}$ quarter & 100 & 57 & 43 \\
\hline $2^{\text {nd }}$ quarter & 100 & 59 & 41 \\
\hline $3^{\text {rd }}$ quarter & 100 & 59 & 41 \\
\hline $4^{\text {th }}$ quarter & 100 & 58 & 44 \\
\hline Year & 100 & & 42 \\
\hline & 2015 & 61 & 39 \\
\hline
\end{tabular}

Source: Rosstat.

Table 3

THE SHARE OF CONSUMPTION GOODS, INTERMEDIATE GOODS AND INVESTMENT GOODS IN TOTAL IMPORTS, \%

\begin{tabular}{|l|c|c|c|}
\hline & \multicolumn{4}{|c|}{$\begin{array}{c}\text { Goods } \\
\text { tionsump- }\end{array}$} & $\begin{array}{c}\text { Investment } \\
\text { goods }\end{array}$ & $\begin{array}{c}\text { Interme- } \\
\text { diate goods }\end{array}$ \\
\hline \multicolumn{5}{|c|}{2014} \\
\hline $1^{\text {st }}$ quarter & 38.3 & 23.1 & 38.6 \\
\hline $2^{\text {nd }}$ quarter & 34.7 & 26.1 & 39.2 \\
\hline $3^{\text {rd }}$ quarter & 35.6 & 23.4 & 41.0 \\
\hline $4^{\text {th }}$ quarter & 36.5 & 25.2 & 38.3 \\
\hline Year & 36.1 & 24.5 & 39.4 \\
\hline & \multicolumn{3}{|c|}{2015} \\
\hline $1^{\text {st }}$ quarter & 36.4 & 21.4 & 42.2 \\
\hline
\end{tabular}

Source: Rosstat.

Enterprises producing intermediate demand products, with a high percentage of export-focused enterprises, responded to the increase in prices due to depreciation of the ruble by recovering their output, however this manufacturing segment saw a decline in production since April 2015. The decline in the output of intermediate consumption goods resulted in structural changes in imports: the share of intermediate goods in total imports in Q1 2015 increased to 42.2\% compared to $38.6 \%$ last year.

Investment-complex entities responded most sharply to the shift in domestic market conditions fol-

1 See Section 1, OMES No. 10, 2015. lowing an increase in prices of imported intermediate and end-consumption products.

On a year-over-year basis, the index of manufacture of means of transport and equipment in May 2015 stood at $82.2 \%$ (a decline of $32.2 \%$ in the manufacture of motor vehicles and $11.9 \%$ in the manufacture of vessels, aircraft and spacecraft and other means of transport), manufacture of machinery and equipment at $75.1 \%$, and manufacture of electrical, electronic and optical at $87.6 \%$. The situation in these branches of economic activity was aggravated by a $21.8 \%$ decline in the volume of imports of high-technology products including electronic and communication equipment (down 27.3\%), goods for the aerospace industry (down $41.5 \%)$ compared to Q1 2014. However, note that growth rates in exports of high-technology products remained within positive values as the ruble' exchange rate changed, thereby having a positive effect on the performance results of the respective branches.

Table 4

EXPORTS AND IMPORTS OF HIGH-TECHNOLOGY PRODUCTS IN Q1 2013-2015, MILLIONS OF US\$

\begin{tabular}{|c|c|c|c|c|c|c|}
\hline & \multicolumn{3}{|c|}{ Exports } & \multicolumn{3}{|c|}{ Imports } \\
\hline & 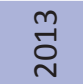 & 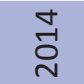 & 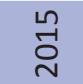 & $\stackrel{\text { m }}{\stackrel{-}{\circ}}$ & 茫 & 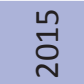 \\
\hline $\begin{array}{l}\text { High-technology } \\
\text { products }\end{array}$ & 5084 & 2950 & 4287 & 9544 & 8468 & 6615 \\
\hline $\begin{array}{l}\text { including: } \\
\text { airspace industry } \\
\text { products }\end{array}$ & 2268 & 1107 & 1269 & 2136 & 2001 & 1151 \\
\hline $\begin{array}{l}\text { computer } \\
\text { hardware and } \\
\text { office equipment }\end{array}$ & 55.2 & 124 & 940 & 1440 & 1320 & 1708 \\
\hline $\begin{array}{l}\text { electronics and } \\
\text { telecommunica- } \\
\text { tions equipment }\end{array}$ & 203 & 215 & 238 & 2861 & 2428 & 1775 \\
\hline $\begin{array}{l}\text { pharmaceutical } \\
\text { products }\end{array}$ & 42.6 & 52.2 & 38.7 & 932 & 697 & 542 \\
\hline $\begin{array}{l}\text { scientific } \\
\text { research } \\
\text { instruments }\end{array}$ & 194 & 301 & 147 & 1054 & 883 & 582 \\
\hline
\end{tabular}

Source: Rosstat.

The production dynamics as it developed had an adverse effect on the market. The general unemployment rate in May 2015 (the calculations were made using the ILO method) stood at $5.6 \%$ compared to $4.9 \%$ last year. The number of unemployed individuals increased $13.5 \%$ in comparison to May 2014, making up a total of 4292,000 persons.

The fall of living standards became a factor for economic expansion, because wages account for almost $70 \%$ of personal incomes. The labor market in April-May 2015 was characterized by a decline in the general unemployment rate and the recorded unem- 
THE LABOR MARKET KEY INDICATORS IN JANUARY-MAY 2015

\begin{tabular}{|c|c|c|c|c|c|}
\hline & January & February & March & April & May \\
\hline $\begin{array}{l}\text { The labor force participation rate } \\
\text { (individuals currently in the labor force to the } \\
\text { number of individuals at the age of } 15 \text { to } 72 \text { ) }\end{array}$ & 68.5 & 68.4 & 68.7 & 68.6 & 69.5 \\
\hline $\begin{array}{l}\text { The employment rate (employed individuals to the } \\
\text { number of individuals at the age of } 15 \text { to } 72 \text { ) }\end{array}$ & 64.8 & 64.5 & 64.7 & 64.7 & 65.6 \\
\hline $\begin{array}{l}\text { The unemployment rate (unemployed individuals to } \\
\text { the number of individuals currently in the labor force) }\end{array}$ & 5.5 & 5.8 & 5.9 & 5.8 & 5.6 \\
\hline
\end{tabular}

Source: Rosstat.

ployment rate after the high hit in March, when the general unemployment rate was $5.9 \%$, the highest since February 2013. In May 2015, the total number of unemployed individuals was 128,000 less than that in the previous month, and the number of unemployed individuals officially registered with employment services decreased by 13,000 . The statistically reported figures showing an improvement in the labor market performance might cover $9.6 \%$ of part time workers in Q1 2015 in the average number employed. However one cannot rule out that job seekers may be less picky while seeking vacancies under the circumstances.

According to the Gaidar Institute updated forecast, end-year (2015) GDP is estimated to decline within a range of, depending on crude oil prices, $2.8 \%$ (the baseline forecast) and $4.2 \%$ (the pessimistic forecast), while fixed investment and retail turnover are expected to decrease respectively within $8.8-9.0 \%$ and $5.8-7.2 \%^{1}$.

1 See Section 1, OMES No. 10, 2015 for more details. 